\title{
Impactos do Parlamento Jovem Brasileiro na imagem pública do Poder Legislativo na visão dos egressos
}

\author{
Antonio Teixeira de Barros \\ Centro de Formação, Treinamento e Aperfeiçoamento da Câmara dos Deputados (Cefor)
}

Lúcio Meireles Martins

Centro de Formação, Treinamento e Aperfeiçoamento da Câmara dos Deputados (Cefor)

Avaliam-se os impactos do Parlamento Jovem Brasileiro (PJB) nas percepções políticas dos egressos, quanto à imagem pública do Poder Legislativo. A imagem pública está diretamente relacionada com a confiança institucional. Dessa forma, avalia-se a correlação desses dois aspectos. A análise é guiada pela seguinte indagação: eventuais impactos positivos de um projeto institucional de simulação parlamentar para jovens podem interferir na visão dos egressos sobre a imagem institucional e a confiança política? A análise baseiase em levantamento do tipo survey, com questionário aplicado on-line, em 2014, com $27,93 \%$ do universo estudado. A principal conclusão é que o PJB exerceu efeitos duradouros nos egressos, tanto em relação à melhoria da imagem do Poder Legislativo quanto ao fortalecimento da confiança política.

Palavras-chave: imagem pública, educação política, comportamento humano, poder legislativo

[Artigo submetido em 8 de setembro de 2015. Aprovado em 8 de agosto de 2016.] 
Efectos del Parlamento de la Juventud en la imagen pública de la Legislatura en opinión de los participantes graduados

Este artículo evalúa los impactos del Parlamento Brasileiro de la Juventud (PJB) en las percepciones políticas de los graduados, en relación a la imagen pública de la Legislatura. La imagen pública está directamente relacionada con la confianza institucional. De esta manera se evalúa la correlación de estos dos aspectos. El análisis se guía por la siguiente pregunta: ¿los impactos positivos de un proyecto institucional de simulación parlamentaria pueden interferir con la visión de la imagen institucional y la confianza política de los participantes? El análisis se basa en el tipo de encuesta con cuestionario en línea aplicada en 2014, con $27,93 \%$ del universo de estudio. La principal conclusión es que lo PJB ejerce efectos duraderos sobre los jóvenes, tanto en términos de mejora de la imagen de la legislatura, como el fortalecimiento de la confianza política.

Palabras clave: imagen pública, educación política, comportamiento humano, poder legislativo

Effects of the Brazilian Youth Parliament project in the public image of Legislature in the view of former participants

The article analyses the effects of the Brazilian Youth Parliament (PJB) in political perceptions of the participants. The public image is directly related to the institutional trust. Thus, we evaluate the correlation of these two aspects. The analysis is guided by the following question: possible positive effects of an institutional project of parliamentary simulation for young people can interfere in institutional image and political trust? The analysis is based on a survey applied online in 2014, with $27.93 \%$ of the universe studied. The main conclusion is that the PJB effects are permanent in the image of Legislature and about the improving of political trust.

Keywords: public image, political education, human behavior, legislative power 


\section{Introdução}

O artigo tem como objetivo principal analisar os impactos do Parlamento Jovem Brasileiro (PJB) nas percepções políticas dos egressos. O foco específico da pesquisa são os efeitos do PJB na imagem pública do Poder Legislativo segundo a perspectiva dos jovens egressos. A imagem pública está diretamente relacionada com a confiança institucional, dessa forma avalia-se a correlação dessas duas perspectivas. O levantamento foi guiado pela seguinte indagação: eventuais impactos positivos de um projeto institucional de simulação parlamentar juvenil podem interferir na percepção dos egressos sobre a imagem pública do Poder Legislativo?

A análise está baseada em levantamento do tipo survey, com questionário aplicado on-line em 2014. Os ex-participantes das edições de 2004 a 2013 (10 eventos) foram contatados via e-mail e Facebook, quando foram convidados a preencher um questionário com questões abertas e fechadas. Do total de 762 jovens que participaram do projeto nas dez edições mencionadas, 176 responderam ao questionário, representando $23,09 \%$ do universo estudado.

Intentou-se a realização de um censo junto aos participantes e ao final da coleta de dados, optou-se pela exclusão das respostas relativas aos dois anos iniciais (2004 e 2005), em vista do baixo índice de respostas advindo da dificuldade de contato com esse grupo ${ }^{1}$. Assim, a análise final contempla oito anos de execução do PJB, isto é, de 2006 a 2013, totalizando 169 respondentes, o que corresponde a $27,93 \%$ do total de egressos das oito edições mencionadas. Essa decisão se baseia nas diversas características desse público analisado no estudo, entre elas, gênero, idade, moradia em capital ou cidade do interior e escolaridade, já que a análise de uma amostra com apenas duas (2004) ou cinco (2005) respostas não abarcaria esses variados fatores necessários à compreensão dos fenômenos estudados.

\section{Imagem pública e confiança institucional}

A imagem pública dos governantes, das instituições e de seus representantes exerce um papel fundamental na vida política, uma vez que está diretamente associada ao capital simbólico da credibilidade e da confiança, o que tem reflexo direto na reputação institucional (GoMES, 2006). Afinal, complementa Baldissera (2008, p. 197), "a imagem-conceito contempla a noção de reputação, pois formar conceito implica apreciar, considerar, ajuizar, sentenciar e sancionar". Trata-se, portanto, de uma forma simbólica, nos termos de Thompson (1995), ou seja, expressão significativa produzida, transmitida e recebida em contextos e processos

\footnotetext{
${ }^{1}$ Vale ressaltar que os grupos iniciais ainda não dispunham das facilidades de contato eletrônico como no período mais recente.
} 
historicamente específicos e socialmente estruturados. Em razão disso, a imagem pública, entendida como forma simbólica, é passível de "complexos processos de valorização, avaliação e conflitos" (THOMPSON, 1995, p. 203). A valorização ocorre no plano simbólico, por meio da aprovação ou rejeição da imagem pública projetada para a opinião pública. Essa valorização simbólica implica, portanto, constante avaliação e conflito, em função das dinâmicas de visibilidade.

\section{Imagem pública e visibilidade}

A imagem pública é consequência da visibilidade, uma vez que aquilo que é mostrado produz efeitos cognitivos e simbólicos no público (GOMES, 2004). Como define Weber (2004, p.265), "a imagem pública é resultante da imagem conceitual, emitida por sujeitos políticos em disputa de poder e recuperada na síntese de imagens abstratas (o intangível, a imaginação), com as imagens concretas (o tangível, os sentidos)".

Além da performance dos media, operadores por excelência da visibilidade, a imagem pública depende ainda de fatores político-institucionais e de características da cultura política (NOLETo FILHo, 2014). Isso significa que as percepções públicas sobre determinada instituição e seus representantes dependem do modo como a própria instituição se relaciona com a sociedade e de como essa mesma sociedade constrói suas representações políticas. Por essa razão, trata-se de um "conceito híbrido forjado na combinação de visibilidades e segredos" (WEBER, 2009, p. 11), a partir da articulação entre os três fatores mencionados, com forte impacto na reputação institucional.

Existe, portanto, um processo de reciprocidade entre instituição e sociedade no processo de construção da imagem pública, com base na comunicação mediada:

A imagem pública pode ser formulada sobre o "reconhecimento" da instituição ou sujeito que fala sobre o tema que adquire significado na recepção a partir da identificação da sua "representatividade, legitimidade, autoridade, autonomia, compromisso" com o tema. Influenciam na formulação dessa opinião a modalidade discursiva, as mídias e os emissores de informações sobre o tema em questão, especificamente, como notícia, opinião, propaganda; rádio, televisão, internet, mídia impressa; manifestação pública; comunicação institucional, eventos ou comunicação mediática (...). Quanto maior a repercussão do tema para a vida do indivíduo, da sua classe, da sociedade, maior será sua capacidade seletiva e, consequentemente, a reunião de dados e informações ampliando a sua possibilidade de formar criticamente uma imagem pública sobre as instituições e sujeitos em questão (WEBER, 2009, p. 22). 
A construção da imagem pública está associada, portanto, à produção e divulgação de opiniões e à consequente adesão do público a determinadas formas de pensar. Afinal, a política se baseia na capacidade de formar opinião (ARENDT, 1983). Enquanto as ciências exatas e naturais operam com evidências racionais ou provas empíricas expressas em definições, postulados, teoremas e similares (discursos monológicos), a política situa-se no campo dialógico da pluralidade de ideias, uma vez que se trata de uma atividade que se instaura na relação entre os homens, ou seja, a pluralidade está na sua própria origem e a visibilidade lhe é inerente (THOMPSON, 1995). Tal raciocínio conduz ao pressuposto de que a política se situa no âmbito da opinião, com todas as implicações positivas e negativas.

Um conceito central, nessa ordem de ideias, é o de opinião pública², em sua relação direta com as práticas políticas e a construção da imagem pública. A esse respeito, cabe ressaltar que, no âmbito da Ciência Política, no Brasil, os estudos sobre opinião pública ocupam-se mais do comportamento eleitoral do que propriamente da formação da opinião. As principais explicações para o comportamento eleitoral vêm de duas principais vertentes: a teoria da escolha racional e a perspectiva sociológica (CASTRO, 1992). Entendemos a primeira, resumidamente, como aquela que explica comportamentos políticos considerando os cidadãos como racionais e sempre com intenção de maximizar seus ganhos, obviamente com pequenas variações teóricas entre os autores que trabalham com essa base (Downs, 1957; FIORINA, 1981). E a segunda, como aquela que explica a direção do voto também por variáveis de tipo social e comunicacional, ligadas à participação política, como grupo social, escolaridade, exposição à propaganda etc. (CASTRO, 1992; KEY, 2013; Figueiredo, 1991; AldÉ et al., 2007).

Em seu processo de conceituação geral, a opinião pública concentra um dos debates mais polêmicos e inacabados na atualidade (CERVI, 2006, p. 132). Recorremos aqui a uma síntese conceitual, a partir das contribuições de autores como Nikas Luhmann (2005), Walter Lippmann (2008) e Habermas (1971, 1984) 3 .

Luhmann (2005) analisa a opinião pública como indissociável da democracia. Afinal, o sistema político é baseado em variadas formas de comunicação, informação e opinião. Existe, portanto, um acoplamento estrutural entre o sistema político e a opinião pública. Por essa razão, os media exercem papel central na função de legitimação de determinadas correntes de opinião. Esteves (2005, p. 289) resume

\footnotetext{
${ }^{2}$ Não é objetivo deste trabalho discorrer sobre a complexidade teórica envolvida na discussão sobre o conceito de opinião pública, até porque não haveria espaço para tal. Um panorama dessa discussão, do ponto de vista da Ciência Política, é formulado por Cervi (2006).

${ }^{3}$ Utilizamos na realidade os pontos de convergência teórica entre esses autores, com a ressalva de que o pensamento de cada um deles é portador de particularidades que não cabem aqui, principalmente pela falta de espaço.
} 
como essa função é exercida pelos meios de comunicação, os quais fornecem diariamente aos cidadãos as motivações necessárias à aceitação das "formas elementares de sentido" que sustentam as decisões políticas e produzem um efeito de "generalização normativa", por meio de uma "linguagem funcionalizada" da política. Isso produz impacto na seleção temática, reduzindo a complexidade da agenda a alguns núcleos, os quais se mostram ajustáveis às dinâmicas decisórias do sistema político. Dessa forma, a opinião pública assume a função de "mecanismoguia" do sistema político, "que não determina o que é verdadeiro, nem o exercício do domínio, nem a formação da opinião, mas só estabelece os limites daquilo que é progressivamente possível" (ESTEVES, 2005, p. 317-318).

Walter Lippmann (2008) também discute a legitimidade da opinião pública, ao questionar a relação entre os fatos, a divulgação deles e a imagem formada individualmente pelos cidadãos. Em outras palavras, o autor discute a natureza da mediação simbólica protagonizada pelos media, uma vez que a realidade é inacessível diretamente pelos indivíduos em seus diferentes mundos privados. Para Lippmann (2008), há uma série de fatores que interferem na transmissão de imagens, informações e opiniões, a começar pelas limitações técnicas dos media, padronizações e formatos, além dos estereótipos e eventuais restrições na divulgação de determinados temas. Em relação ao público, o autor chama atenção para outro conjunto de fatores que também podem interferir, como o interesse do público, o grau de conhecimento dos temas abordados e a falta de acesso direto ao contexto originário dos acontecimentos. A opinião reconhecida como pública resulta, portanto, de variados fatores que condicionam sua conformação, a exemplo da ação articulada de grupos de interesse que utilizam a vitrine dos media. Assim, trata-se de uma opinião que se torna pública, mas não nasce do público.

Habermas (1971, 1984), por sua vez, associa o conceito de opinião pública à noção de publicidade, ou seja, às dinâmicas de debate público de argumentos que interessam a um público. A publicidade remete, em termos gerais, ao estatuto daquilo que é público, à qualidade ou estado das coisas públicas (tornar público). Na visão habermasiana, nas sociedades democráticas os media exercem a função de "enfeixar" as distintas correntes de opinião, por meio de ação instrumental que seletivamente exclui determinados assuntos da discussão pública, enquanto acentua politicamente a inserção de outros temas.

Essa ação instrumental produz efeitos nos processos de formação, circulação e de expressão da opinião pública. O autor atribui à opinião pública (no sentido midiático) a função de legitimar o domínio político por meio de um processo estratégico de comunicação sustentado nos princípios de um consenso que deixa de ser racionalmente motivado e torna-se estrategicamente orientado. Assim, a esfera pública originalmente entendida pelo autor como instância ativa da opinião pública, 
torna-se uma instância meramente receptiva, em que os indivíduos "isolados e sem possibilidade de comunicação real com os representantes de instituições políticas, reagem apenas aclamando, enquanto os representantes usam esse espaço para a divulgação manipulativa das mensagens" (CERVI, 2006, p. 115).

Em resumo, apesar da complexidade e da amplitude do debate, alguns autores assinalam que a opinião pública constitui, portanto, uma espécie de consenso socialmente construído ou induzido, embora isso não signifique unanimidade (CHAMPAGNE, 1988). Converge para a coincidência da atenção pública em relação a determinadas questões ou temas, mas sem necessariamente implicar adesão dóxica generalizada da população. O debate coletivo contribui para fortalecer a opinião pública.

Em termos mais abrangentes, a opinião pública reflete as ideias culturais de uma sociedade, como os valores que conformam seu ethos cultural (JOHNSON, 1997). Por essa razão, os processos de formação da opinião pública são considerados de grande relevância para as ciências sociais. Nessa perspectiva, Matteucci (1986), Champagne (1998) e Viá (1983) consideram que a opinião pública nasce pública, ou seja, é manifestada publicamente, com o respaldo de um grupo, de uma classe ou de uma elite e se refere a algo de interesse público. Isso significa que o debate coletivo é o tônico que fortalece a opinião pública. Quando bem conduzido, o debate pode tornar a discussão mais racional e crítica, isto é, pode depurar os juízos de valor e ressaltar os juízos de fato, tornando a opinião pública mais racional e crítica. Como opinião (doxa), "é sempre discutível, pois muda com o tempo e permite a discordância" (MATTEUCCI, 1986, p. 842). "Enquanto 'pública', isto é, pertencente ao âmbito político, conviria antes falar de opiniões no plural, já que nesse universo não há espaço apenas para uma verdade, para uma epistemocracia" (MATTEUCCI, 1986, p. 842).

Dessa forma, a opinião pública transcende a mera soma das opiniões individuais, uma vez que é formada em contextos de debates coletivos e se refere a algo de interesse público. Por essa razão, no sentido moderno, a opinião pública pressupõe uma sociedade civil distinta do Estado, livre e articulada.

Para Thiollent (1986, p. 156), “A opinião pública é uma noção comumente utilizada para designar o que a maioria da população de um país julga, gosta, prefere em matéria de política, de economia ou de outros assuntos de importância nacional ou internacional". Assim, a opinião pública não é a simples adição das opiniões individuais, pois sua formação e sua significação dependem do contexto nacional ou internacional, do governo, dos partidos políticos, das grandes empresas, dos meios de comunicação de massa etc. A opinião pública é determinada por todos esses fatores e se apresenta como espaço no qual se opõem diversas tendências ideológicas, sendo que uma delas é majoritária. 
Segundo Augras (1978, p. 24-46), existem três fatores relevantes que interferem na formação da opinião pública. Os fatores psicológicos situam-se no nível interpessoal, ou seja, a formação de atitudes e opiniões; motivações e mecanismos de defesa; além das crenças, valores e capacidade cognitiva. Os fatores sociais situam-se no nível da convivência coletiva, no qual as opiniões individuais são influenciadas pelos grupos sociais primários, secundários e de referência. Os fatores históricos estão relacionados com a conjuntura macropolítica, a qual condiciona as opiniões, de acordo com a tendência a maior ou menor liberdade de expressão.

As controvérsias de ampla repercussão pública são consideradas as ocasiões mais férteis para as manifestações coletivas de opinião. Controvérsias ocorrem nas dinâmicas alimentadas pelo debate público, o qual pressupõe pluralismo, ou seja, a pluralização de universos divergentes de discurso (HABERMAS, 1999, 2002). As múltiplas visões sobre uma mesma questão discutida na esfera pública devem-se pautar, segundo a abordagem habermasiana, pela racionalidade comunicativa, ou seja, as controvérsias devem ser tratadas sem coerção moral, em um ambiente comunicativo capaz de instituir um consenso racionalmente construído. Isso implica um clima de debate no qual os participantes superam suas concepções inicialmente subjetivas e parciais em favor de um acordo racionalmente motivado (HABERMAS, 2002).

Nessa perspectiva, quanto mais livres e seguros os indivíduos se sentirem, no que se refere à exposição de seus argumentos, mais as controvérsias prosperam, levando ao que Bauman (2010, p. 177) denomina de "exacerbação das controvérsias" ou "a pluralidade histórica das verdades". Afinal, complementa: "em um mundo pluralista, não há nenhum sistema inconteste de definição da realidade" (BAUMAN, 2010, p. 178). Por outro lado, o autor alerta para o risco de o pluralismo se transformar em absolutismo múltiplo, ou seja, as controvérsias são regidas por lógicas autoritárias de argumentação e construção de consensos.

Para que efetivamente haja pluralismo, segundo Bauman (2010), não basta a coexistência de visões diferentes e um relativo clima de liberdade de opinião. 0 pluralismo, em sua visão, vai além disso, pois compreende a existência de múltiplas estruturas de referência, cada qual com seu próprio esquema de compreensão e seus próprios critérios de racionalidade. "Pluralismo é a coexistência de posições comparáveis e rivais que não se podem conciliar. Pluralismo é o reconhecimento de que diferentes pessoas e diferentes grupos vivem, literalmente, em mundos diferentes" (BAUMAN, 2010, p.178).

Cada vez mais a esfera pública assume papel relevante nas dinâmicas de visibilidade e discutibilidade das denúncias e causas públicas, inserindo os diversos atores na construção argumentativa em torno das questões suscitadas pela repercussão das controvérsias. Isso favorece a formação de diversos tipos 
de comunidades discursivas e comunidades de interesse, que passam a mobilizar diferentes modalidades de recursos críticos em seus modos de apresentar suas críticas e justificações, nas diferentes cadeias de mediação proporcionadas pela atuação cada vez mais ramificada das mídias digitais. Afinal de contas,

En nuestras sociedades todos los actores disponen, en effecto, de capacidades críticas, y puden movilizar, aunque sin duda de manera desigual según la situación, recursos críticos que ponen em práctica en el curso de sus actividades cotidianas. En este sentido, estas sociedades puden ser calificadas como sociedades críticas (BOLTANSKI, 2000, p. 260).

Apesar disso, Bauman (2015, p. 120) refere-se a uma crise nos debates públicos, com o "desaparecimento ou redução das arenas voltadas para a deliberação pública e política". A despeito dessa crise, o autor aponta as ciências sociais como instâncias de saberes diretamente conectados à esfera pública e às experiências humanas. Assim, os cientistas sociais, com sua expertise discursiva e a perícia típica de quem consegue olhar para a realidade e seus contextos, podem contribuir para ampliar o foco dos debates, "num mundo saturado de opiniões que se opõem e que mutuamente corroem sua veracidade real ou suposta" (BAUMAN, 2015, p.105).

O autor chama atenção para os movimentos de opinião denominados por ele de enxames, ou seja, uma conformação social líquida que substitui os grupos sociais. Ao contrário do grupo, entendido sociologicamente como algo dependente de lideranças fortes, hierarquia de autoridade e estruturas de poder (ORTIZ, 2011), o enxame se forma e se dispersa conforme as circunstâncias. Por isso, também são denominados por Bauman (2008a) de comunidades de ocasião, que se formam e se desfazem em torno de um assunto enquanto dura uma controvérsia pública, uma disputa ou uma comoção coletiva (BAUMAN, 2008b).

Ancorada nas ideias de Hannah Arendt e Habermas, Céli Pinto (2004) relaciona a opinião pública com a própria noção de democracia. Para a autora, a livre formação de opinião é uma condição dos regimes democráticos, baseados no princípio de liberdade de expressão. Isso remete à relação entre os conceitos de público, espaço público e de esfera pública, em paralelo com as noções de democracia, liberdade e igualdade. Todos esses conceitos são indissociáveis quando se pensa em democracia, "porque a democracia é, entre outras coisas, o regime da opinião pública, da circulação livre das informações" (PINTO, 2004, p. 46). Dessa forma, a democracia "não pode prescindir de uma esfera pública capaz de ser um espaço para a construção de uma opinião pública" (PINTO, 2004, p. 49). O desafio, segundo a autora, é como pensar em uma esfera pública forte e em uma opinião pública consistente. Refletir sobre opinião pública, constitui, portanto, um dos principais desafios para as teorias democráticas na atualidade. 
Manuel Castells (2003) reforça tal desafio com a emergência das formas virtuais de circulação de opiniões possibilitadas pela internet e seu regime de opiniões em fluxo. Segundo Castells (2003), as mídias digitais ampliaram as possibilidades de produção, emissão e circulação de opiniões, sem o filtro dos meios de comunicação unidirecionais, uma vez que a sociedade em rede é caracterizada pela variedade de formas de expressão de opiniões, possibilitadas pelas tecnologias digitais. 0 autor denominou essa sociedade em rede de sistema de autocomunicação de massas ou de intercomunicação, em função do empoderamento dos usuários das redes informacionais, os quais não dependem mais dos sistemas convencionais de intermediação e controle da opinião. Isso permite uma nova configuração no âmbito das trocas de opiniões, em um regime de maior velocidade e pluralidade.

Ao chamar atenção para a complexidade envolvida nos processos de formação de opinião pública, Pierre Bourdieu (2003) critica as concepções que reduzem a noção de opinião pública às sondagens e pesquisas de opinião. Para o autor, "a opinião, no sentido da definição social implicitamente admitida pelos que fazem sondagens de opinião ou pelos que utilizam os resultados das sondagens de opinião, não existe" (BOURDIEU, 2003, p. 233).

Segundo Bourdieu (2003), essas sondagens estão ancoradas em vários postulados falsos. O primeiro diz respeito às heranças positivistas das amostragens utilizadas, que consideram a sociedade como algo homogêneo, passível de ser representado numericamente por certos percentuais de indivíduos de cada sexo, faixa etária etc. Além disso, as pesquisas de opinião colocam em posição de igualdade opiniões que são qualitativamente diferentes, como a de um especialista ou a de cidadão crítico e bem informado sobre o assunto inquirido e a visão de um indivíduo que desconhece totalmente o tema em debate. Em relação a essa premissa, "a ideia de objetividade numa pesquisa de opinião é associada ao fato de se fazer a pergunta nos termos mais neutros possíveis para dar chances a todas as respostas" (BOURDIEU, 2003, p. 234). Segundo o autor, na maioria das vezes, as questões são formuladas com vieses, levando a resposta a ser induzida por meio da maneira de se colocar a questão.

Outro postulado falso consiste na suposição das sondagens de que todos os indivíduos possuem opinião formada sobre o tema pesquisado, ou seja, "que a produção de uma opinião está ao alcance de todos" (BouRdiEU, 2003, p. 235). Essa premissa desconsidera as condições específicas da produção de opiniões, "que a pesquisa de opinião supõe estarem universal e uniformemente preenchidas", com a ideia implícita de que "todo mundo pode produzir uma opinião" (BOURDIEU, 2003, p. 236). Essa visão "tem como ponto de partida o postulado segundo o qual todo mundo deve ter uma opinião" e "consiste em ignorar as não respostas" (BoURDIEU, 2003, p. 237). Além disso, esse postulado desconsidera que "tem-se muito mais 
opiniões sobre um problema quando se está mais interessado por este problema, isto é, quando se tem mais interesse neste problema" (BOURDIEU, 2003, p. 238). Por essa razão, "as pesquisas de opinião apreendem muito mal os estados virtuais da opinião e mais exatamente os movimentos de opinião", uma vez que "a situação na qual elas apreendem as opiniões é inteiramente artificial" (BOURDIEU, 2003, p. 243).

Conforme Bourdieu (2003), também seria equivocado supor que o interesse dos pesquisadores coincide com o interesse dos pesquisados. "Pelo simples fato de se colocar a mesma questão a todo mundo, está implícita a hipótese de que há um consenso sobre os problemas, ou seja, que há um acordo sobre as questões que merecem ser colocadas" (BOURDIEU, 2003, p. 239). Assim, um dos efeitos mais perniciosos da pesquisa de opinião "consiste precisamente em colocar pessoas respondendo a perguntas que elas não se perguntaram" (BOURDIEU, 2003, p. 241). O efeito de imposição da problemática é exercido por qualquer pesquisa de opinião e por qualquer interrogação política. Tal efeito resulta do fato de que as perguntas colocadas numa pesquisa de opinião "não são perguntas que realmente se colocam a todas as pessoas interrogadas e as respostas não são interpretadas em função da problemática que servia efetivamente como referência às diferentes categorias de inquiridos" (BOURDIEU, 2003, p. 240).

Para o autor,

As problemáticas que são propostas pelas pesquisas de opinião se subordinam a interesses políticos, e isto dirige de maneira muito acentuada o significado das respostas e, ao mesmo tempo, o significado dado à publicação dos resultados. Em seu estado atual, a pesquisa de opinião é um instrumento de ação política; sua função mais importante consiste talvez em impor a ilusão de que existe uma opinião pública que é a soma puramente aditiva de opiniões individuais; em impor a ideia de que existe algo que seria uma coisa assim como a média das opiniões ou a opinião média (BOURDIEU, 2003, p. 241).

No que diz respeito especificamente ao Parlamento, com base no conceito de Habermas (1994), é interessante considerar ainda o que se chama de regime de opinião, instaurado com os primeiros governos liberais, no princípio do século 19. Em um regime de opinião, seria lícito e prudente aos parlamentares consultar a opinião pública, já que a origem do poder em uma democracia é popular (SÁ, 2004; HABERMAS, 1994). Nele há racionalidade e discussão, que confeririam o princípio de autoridade, que pode ser reforçado ou questionado pela população, a depender da natureza da imagem pública dominante e do nível de confiança da sociedade nas instituições políticas, conforme será abordado a seguir. 


\section{Confiança e imagem pública}

A confiança institucional é um dos elementos centrais da modernidade, na forma de credibilidade pública, o que se reflete diretamente na imagem e na reputação de governos e instituições públicas. Trata-se de "uma forma de fé na qual a segurança adquirida em resultados prováveis expressa mais um compromisso com algo do que apenas uma compreensão cognitiva" (GIDDENS, 1990, p. 29). Dessa forma, a confiança expressa no nível de adesão ao regime democrático e na utilização das instituições oficiais constitui um fator simbólico de suma importância para a estabilidade política e institucional.

Como assinala Miguel (2003, p. 123), há uma "deterioração da adesão popular às instituições representativas", especialmente sob o ponto de vista liberal de democracia adotado por autores como Schumpeter. Em outra obra, Miguel (2005) faz uma síntese dos estudos que apontam uma crise da representação ou da democracia nos países ocidentais nos anos 1970 e 1990 do século passado e que revelam "o descrédito generalizado das instituições representativas entre os cidadãos comuns" (MIGUEL, 2005, p. 27). A confiança, portanto, pode se tornar um antídoto às recorrentes crises das democracias (McCoY, 2000).

Vários outros autores (PORTO, 1996; BOSCHI, 2004; STOKER, 2006; DALTON, 2007; MoIsÉs, 2009) enfatizam a crise de descrédito por que passam as instituições políticas contemporâneas. Pesquisas recentes revelam que o nível de confiança da população nas instituições políticas nunca foi tão baixo, especialmente em relação às casas legislativas (LESTON-BANDEIRA, 2012). Essa desconfiança nos políticos, o ceticismo em relação a instituições democráticas e a desilusão com o processo democrático chegam a ser apontados por Dalton (2007) e Stoker (2006) como o grande desafio das democracias contemporâneas, já que é comum a todas as democracias industriais avançadas. A desconfiança é apontada em vários estudos da ciência política ${ }^{4}$ como efeito da percepção da corrupção e ênfase dos media em informações sobre condutas inadequadas de parlamentares e figuras da vida pública (POWER; JAMINSON, 2005). O desenvolvimento de uma cidadania cada vez mais crítica e vigilante também é apontado como um dos fatores do aumento da desconfiança (RIBEIRO, 2011).

Boschi (2004, p. 3) explica que isso se deve à ausência de resultados substantivos das instituições democráticas, que correspondam às expectativas dos cidadãos em relação a mudanças, revelando um descompasso muito grande entre o que chama de democracia formal e democracia substantiva no Brasil e na América Latina em

\footnotetext{
${ }^{4}$ Para um panorama desses estudos, ver Power e Jaminson (2005); Colen (2010); Lopes (2004); Ribeiro (2011); entre outros.
} 
geral, com implicações sobre a qualidade da democracia. Ainda que certo grau de desconfiança seja necessário para garantir a fiscalização ou para estimular reformas e melhorias no processo democrático, a confiança é importante, se não para a existência da democracia, ao menos para sua vitalidade (TILlY, 2008; NoRRIS, 1999; LIJPHART, 2001).

Dessa forma, as instituições políticas surgem como "fatores de diminuição de risco" (FERES JúNIOR; EISENBERG, 2006, p. 471), pois seu funcionamento adequado inibe previamente os potenciais quebradores de confiança e possibilita a reparação dos danos causados pelo não cumprimento das regras por alguns. Para os autores, as instituições servem como espaço de discussão e deliberação de três tipos de demandas sociais em um regime democrático: reconhecimento, redistribuição e revisão das regras das próprias instituições (FERES JúNIOR; EISENBERG, 2006, p. 473).

O fato é que o debate sobre democracia está diretamente relacionado com a questão da confiança do cidadão nas instituições. A discussão está conectada à ideia de que a confiança da população nas instituições de seus países ou comunidades é um aspecto essencial para a legitimidade do regime político e, portanto, para a estabilidade do sistema social. De maneira geral, podemos dizer que quanto mais confiança nas instituições, maiores as chances de desenvolvimento de um regime democrático satisfatório para a população (DAHL, 1989; NORRIS, 1999; LIJPHART, 2001; TILly, 2008). No sistema representativo, com parlamentos, isso adquire ainda mais importância.

Estudos empíricos internacionais mostram que, embora a confiança nas instituições políticas esteja em declínio, o mesmo não se verifica quando se trata das pesquisas sobre a adesão dos cidadãos à democracia. A interpretação do fenômeno é complexa e multifacetada. Por um lado, há análises que associam a desconfiança ao avanço da cidadania crítica, como é o caso de Pipa Norris (1999). Para a autora, quanto mais críticos os cidadãos se tornam, mais exigem dos representantes e das instituições. Em perspectiva contrária, o argumento mais citado baseia-se na visão de Clauss Offe (1999), segundo o qual a desconfiança generalizada dos cidadãos nas instituições e nos governantes pode comprometer a relação entre governantes e governados, uma das bases de sustentação dos regimes democráticos.

No caso do Brasil e das demais jovens democracias latino-americanas, os estudiosos apontam que elas padecem da "síndrome de desconfiança generalizada" (POWER; JAMINSON, 2005; COLEN, 2010; LOPES, 2004; RIBEIRO, 2011). Mas seriam as causas da desconfiança política na América Latina as mesmas identificadas nas democracias avançadas? Segundo Ribeiro (2011), as razões são distintas e as explicações devem ser buscadas no contexto cultural e histórico. Enquanto nas democracias consolidadas a desconfiança é fruto do elevado nível de 
escolarização e informação dos cidadãos críticos, nas jovens democracias latinas a explicação estaria na desilusão dos cidadãos com o funcionamento concreto das instituições políticas, principalmente os parlamentos. Em um ambiente social marcado por extremas desigualdades, a percepção dos cidadãos de que os sistemas político e econômico "beneficiam diferentemente os indivíduos pode levar a uma sensação de que as instituições não são confiáveis" (COLEN, 2010, p. 5). Essa "síndrome cultural latino-americana" teria se enraizado no modo de vida dos cidadãos dessas jovens democracias, estruturando, assim, "uma convivência marcada entre as pessoas e, por decorrência, pela desconfiança em relação às instituições do Estado" (COLEN, 2010, p. 4).

O Brasil segue em percursos interpretativos distintos das democracias industriais avançadas. A baixa confiança, nesse cenário, se mostra próxima a sentimentos de apatia e distanciamento com relação aos aspectos políticos, não refletidos em atitudes de crítica para com o sistema. Cabe ressaltar que os sentimentos de distanciamento e apatia não podem ser generalizados, como vimos nas ondas de manifestações públicas pelas ruas de dezenas de cidades brasileiras, especialmente no caso das chamadas jornadas de junho de 2013. Esses apontamentos nos levam a confirmar a necessidade de se pautarem os estudos sobre cultura política com base em suas realidades contextuais, longe dos padrões vigentes em democracias industriais avançadas. Em suma, no contexto brasileiro, há momentos de retraimento da sociedade civil, mas também há momentos de efervescência e mobilização popular.

Outra observação pertinente é de que os parlamentos não são o foco exclusivo da desconfiança da população, mas são um ponto de concentração de desconfiança. Norris (2011, p. 103) chama atenção, em estudo comparativo de 11 países, para o fato de que a confiança nessa instituição específica apresenta queda significativa ao longo do tempo.

Em relação à juventude, levantamentos mostram até $82 \%$ de desinteresse dos jovens pela política em suas modalidades institucionalizadas ${ }^{5}$ (BAPTISTA et al., 2013). Isso se deve principalmente à recorrente associação entre política e corrupção, o que reforça o pessimismo e a descrença da juventude:

Descrentes da política, desconfiados das instituições representativas, suspeitosos em relação à organização do processo eleitoral e com poucas expectativas de serem ouvidos pelas lideranças, os jovens acabam por participar pouco da vida política. Constata-se uma reduzida experiência

\footnotetext{
${ }^{5}$ Trata-se da pesquisa Juventude, Participação e Voto, realizada por pesquisadores da Universidade Federal de Minas Gerais, em 2010. Disponível em: http://www.opiniaopublica.ufmg.br/pesquisas_detalhe.php?id=41
} 
associativa e, mesmo, certa tendência a que essa participação fique ainda menor. Apenas $18,8 \%$ deles participam de organizações como partidos políticos, sindicatos, organizações não governamentais, associações de bairro, religiosas ou estudantis. Atualmente, a principal forma de os jovens participarem é por meio de associações religiosas (8,4\%). 0 ingresso em partidos políticos $(1,4 \%)$ ou mesmo em associações estudantis $(2,6 \%)$ é praticamente nulo (TELLES; DIAS, 2010, p. 97).

Diante desse cenário, importa avaliar como o PJB interfere na relação dos egressos com a política, sob o ângulo específico da imagem pública do Poder Legislativo e da confiança política.

\section{O Parlamento Jovem Brasileiro}

O PJB é um projeto anual de simulação parlamentar juvenil. Estudantes do ensino médio e técnico de escolas públicas e privadas, entre 16 e 22 anos (2o ou 3응 anos), são convidados a participarem de um concurso de projetos de lei, por meio do qual são selecionados 78 jovens que terão a oportunidade de passar por um processo de formação e prática parlamentar simulada, durante uma semana, na Câmara dos Deputados.

A iniciativa foi idealizada pelo então Deputado Federal Lobbe Netto (PSDB/SP) e instituída como um projeto institucional da Câmara dos Deputados por meio da Resolução $n$ ㅇ 12/2003. Em novembro daquele ano, previa-se inicialmente um projeto a ser desenvolvido em parceria com as instituições representativas estudantis (UNE e Ubes), que promoveriam a seleção por meio de eleições abertas aos estudantes. Percebe-se, assim, que o objetivo inicial do projeto era de formar líderes políticos, dada essa intenção de se vincular ao movimento estudantil. Também se previa alternância de turmas do ensino médio e do ensino superior a cada ano ${ }^{6}$. Porém, já na primeira edição do projeto, em 2004, foi iniciado com outra configuração, bastante semelhante ao formato atual, direcionado aos jovens do ensino médio e com seleção realizada por meio de concurso de redação legislativa. Apesar de alterações pontuais de procedimentos, seja na seleção ou nas atividades didáticas e de simulação, o projeto vem tendo uma constância de seus procedimentos e conteúdos, o que facilita uma análise histórica dos seus resultados. Desde que foi criado, o PJB já realizou 11 edições (2004-2014).

Apesar de não ter se efetivado a participação das instituições estudantis, uma das características do projeto está no envolvimento interinstitucional. O Conselho

\footnotetext{
${ }^{6}$ O Regimento Interno do PJB ainda mantém essas intenções iniciais, apesar das modificações por que passou o projeto: http://www2.camara.leg.br/responsabilidade-social/parlamentojovem/ regimento-interno-do-parlamento-jovem-brasileiro
} 
Nacional de Secretários de Educação (Consed) tem papel essencial na difusão do programa nacionalmente. As secretarias estaduais realizam a divulgação do projeto por meio de releases pré-elaborados, spots de rádio e peças publicitárias impressas oferecidos pela Câmara dos Deputados, e recebem as inscrições com os projetos de lei para uma primeira avaliação de questões documentais obrigatórias. O servidor indicado por cada secretaria de educação também faz uma primeira seleção dos projetos com base em critérios preestabelecidos e os escolhe em até quatro vezes a quantidade de vagas de cada estado. A seleção final dos projetos escolhidos é feita por uma comissão de servidores da Câmara dos Deputados. No mês de março, é realizado um encontro com esses servidores dos estados com diferentes objetivos: avaliação da edição anterior, conscientização quanto à importância da educação política, busca de compromisso com as etapas de organização do programa e apresentação da campanha de divulgação da edição seguinte.

A simulação inclui eleição da Mesa Diretora, debates nas comissões temáticas, além de votação em plenário de proposições, sendo todas as atividades organizadas conforme o Regimento Interno do PJB, homologado pelo Ato da Mesa Diretora da Câmara no 49/2004.

\section{Análise dos resultados}

A análise dos dados inicia-se com a caracterização da amostra estudada, com ênfase para os seguintes aspectos: faixa etária dos respondentes, sexo, ano de participação, região e escolaridade. A análise dos resultados também inclui variáveis como a escolaridade e o local de moradia (capital ou cidade do interior). 0 objetivo dessas informações é contextualizar as respostas dos sujeitos da pesquisa e tentar estabelecer algumas correlações entre as variáveis, a fim de avaliar nos resultados se o tipo de resposta varia em função desses fatores. Além disso, trata-se das variáveis demográficas mais usuais em estudos cujos sujeitos manifestam suas opiniões acerca de determinados temas.

Apesar disso, algumas devem ser justificadas separadamente, como a faixa etária e a escolaridade. A primeira se deve ao fato de que a pesquisa engloba um período de oito anos (2006 a 2013). Portanto, apesar de serem todos jovens, há variações de idade que devem ser consideradas, em consonância com os estudos que recomendam evitar considerar a juventude como algo homogêneo em termos de faixa etária (PEREIRA, 2007). Apesar de se tratar de um público jovem, a resposta ao questionário se deu alguns anos após a participação dos estudantes no PJB, um intervalo de tempo que deve ser considerado. A segunda se justifica por razões similares, ou seja, ao participarem do PJB são todos estudantes do ensino médio, porém, alguns anos depois, ao responderem ao questionário, já passaram dessa 
fase escolar. Cabe ressaltar que a pesquisa foi aplicada após a participação dos jovens no PJB, com turmas de 2006 a 2013.

A amostra estudada inclui participantes de 16 a 29 anos, sendo cerca de $52 \%$ mulheres e $48 \%$ homens. Tal distribuição de idade e gênero pode ser observada na Quadro 1.

Quadro 1 - Idade e sexo dos informantes

\begin{tabular}{|l|l|l|l|l|l|}
\hline Faixa etária & $\mathbf{N}$ & $\mathbf{\%}$ & Gênero & $\mathbf{N}$ & \% \\
\hline 16 a 19 & 55 & 32,54 & Masculino & 88 & 47,93 \\
\hline 20 a 25 & 102 & 60,36 & Feminino & 81 & 52,07 \\
\hline 26 a 29 & 12 & 7,10 & & 169 & 100 \\
\hline Total & 169 & 100 & & \multicolumn{3}{|l|}{} \\
\hline
\end{tabular}

Fonte: Elaboração própria.

Do ponto de vista da faixa etária, predominam os respondentes entre 20 e 25 anos, com 102 registros, equivalente a 60,36\%. Quanto à relação entre o percentual de masculinos e femininos, os dados são coerentes com a realidade nacional e também com o número de eleitores (48\%) e eleitoras (52\%), segundo dados do Tribunal Superior Eleitoral (2014).

Quanto à distribuição por ano, a Quadro 2 mostra um relativo equilíbrio no número de respondentes de cada uma das edições do PJB, com o percentual mínimo de $19,48 \%$, em 2010, e o máximo de 40,51\%, em 2013. Mesmo quando se trata dos menores percentuais, as amostras podem ser consideradas representativas.

\section{Quadro 2 - Quantitativo das amostras por edição}

\begin{tabular}{|l|l|l|l|}
\hline Edição & Amostra & População & Porcentagem \\
\hline 2006 & 17 & 78 & $21,79 \%$ \\
\hline 2007 & 30 & 77 & $38,96 \%$ \\
\hline 2008 & 21 & 78 & $26,92 \%$ \\
\hline 2009 & 18 & 65 & $27,69 \%$ \\
\hline 2010 & 15 & 77 & $19,48 \%$ \\
\hline 2011 & 20 & 81 & $24,69 \%$ \\
\hline 2012 & 16 & 70 & $22,86 \%$ \\
\hline 2013 & 32 & 79 & $40,51 \%$ \\
\hline Total & 169 & 605 & $27,93 \%$ \\
\hline
\end{tabular}

Fonte: Elaboração própria. 
Os egressos que responderam à pesquisa residem em grande parte em cidades do interior ${ }^{7}(64 \%)$ e os demais em capitais, com predomínio de residentes nas regiões Sudeste, Nordeste e Sul, como mostra a Quadro 3. Uma informação complementar relevante é que a amostragem de egressos segmentada conforme a região geográfica é relativamente coerente com a distribuição do eleitorado regional (TRIBUNAL SUPERIOR ELEITORAL, 2014).

A quantidade de vagas do projeto é proporcional ao quantitativo de cadeiras na Câmara dos Deputados que, por sua vez, está vinculada à população dos estados brasileiros. Conforme pode ser verificado na Quadro 3, a realização da pesquisa resultou numa proporção muito próxima entre a amostra e a população de eleitores das regiões, com leve diferença em algumas e um maior percentual na amostra do Sudeste. Considera-se, assim, que os dados levantados têm uma boa representatividade do perfil dos egressos do PJB.

Quadro 3 - Comparação da amostra dos egressos e população de eleitores

\begin{tabular}{|l|l|l|l|l|}
\hline Região & N & $\begin{array}{l}\text { Amostra em } \\
\text { relação à } \\
\text { população de } \\
\text { egressos }\end{array}$ & Eleitores N & Eleitores \% \\
\hline Norte & 15 & $8,87 \%$ & 10.800 .006 & 7,569 \\
\hline Sudeste & 68 & $40,24 \%$ & 61.978 .432 & 43,438 \\
\hline Centro-Oeste & 19 & $11,24 \%$ & 10.230 .760 & 7,17 \\
\hline Nordeste & 40 & $23,67 \%$ & 38.227 .417 & 26,792 \\
\hline Sul & 26 & $15,37 \%$ & 21.092 .096 & 14,783 \\
\hline Exterior & 1 & $0,59 \%$ & 353.598 & 0,248 \\
\hline Total & 169 & 100 & 142.682 .309 & 100 \\
\hline
\end{tabular}

Fonte: Elaboração própria, com dados do TSE - Estatística de eleitorado em novembro de 2014.

Em relação à formação educacional dos egressos, grande parte dos respondentes está em processo de graduação ou já se formou ${ }^{8}(69,05 \%)$. Quando separados apenas aqueles graduados ou graduandos em ciências humanas ou sociais aplicadas, chega-se a um percentual de 47,93\% do geral da amostra, conforme a Quadro 4.

\footnotetext{
${ }^{7}$ As cidades foram classificadas em capital ou cidade de interior, sem uma análise mais detalhada do tamanho das cidades. Cidades de regiões metropolitanas das capitais, quando nomeadas diretamente, foram consideradas cidades do interior, pois isso indicaria uma vinculação maior à localidade mais próxima do que à metrópole.

${ }^{8}$ Cabe ressaltar que os dados se referem ao momento em que os egressos responderam ao questionário e não ao período em que participaram do PJB.
} 


\section{Quadro 4 - Escolaridade dos egressos}

\begin{tabular}{|l|l|l|}
\hline Formação & Quantitativo de respostas & Proporções da amostra \\
\hline Médio e técnico & 33 & $19,53 \%$ \\
\hline Graduação & 116 & $68,64 \%$ \\
\hline Pós-graduação & 20 & $11,83 \%$ \\
\hline Total & 169 & 100 \\
\hline
\end{tabular}

Fonte: Elaboração própria.

\section{Imagem pública do Poder Legislativo}

Em relação à imagem do Poder Legislativo, os resultados mostram um efeito positivo do PJB sobre os jovens participantes. Ao serem indagados se a imagem que eles tinham do Poder Legislativo melhorou ou piorou após a participação no PJB, os percentuais de respostas foram os seguintes: melhorou muito $(47,34 \%)$; melhorou um pouco (36,09\%); permaneceu igual $(6,51 \%)$; piorou um pouco $(4,73 \%)$; piorou muito $(5,33 \%)$, como mostra a Quadro 5. Somadas as duas primeiras alternativas, o percentual chega a $83,44 \%$, um expressivo impacto positivo na imagem pública dos egressos.

\section{Quadro 5 - A imagem do Poder Legislativo após participar do PJB}

\begin{tabular}{|l|c|c|}
\hline Alternativas & N & \% \\
\hline Melhorou muito & 80 & 47,34 \\
\hline Melhorou um pouco & 61 & 36,09 \\
\hline Permaneceu igual & 11 & 6,51 \\
\hline Piorou um pouco & 8 & 4,73 \\
\hline Piorou muito & 9 & 5,33 \\
\hline Total & 169 & 100 \\
\hline
\end{tabular}

Fonte: Elaboração própria.

Quando analisados os resultados para homens e mulheres separadamente, percebe-se uma leve diferença da melhoria da imagem entre os homens, sendo que $53,41 \%$ deles afirmaram que a imagem melhorou muito; já entre as mulheres, apenas 40,74\%. Conforme pode ser observado no Gráfico 1, a percepção da influência do PJB na imagem do Parlamento apresenta relação com o nível educacional dos egressos, pois há uma diminuição do maior nível de mudança da 
imagem conforme aumenta a formação educacional. O percentual de egressos pós-graduados ou pós-graduandos que afirmaram que a imagem piorou após a participação no PJB (2 níveis negativos - 20\%) também reforça essa relação. Contudo, é importante ressaltar que, mesmo nesse público, teoricamente mais crítico, $80 \%$ consideraram alguma melhora da imagem pela participação no projeto (2 níveis positivos).

Gráfico 1 - Impactos do PJB na imagem pública do Poder Legislativo por nível educacional

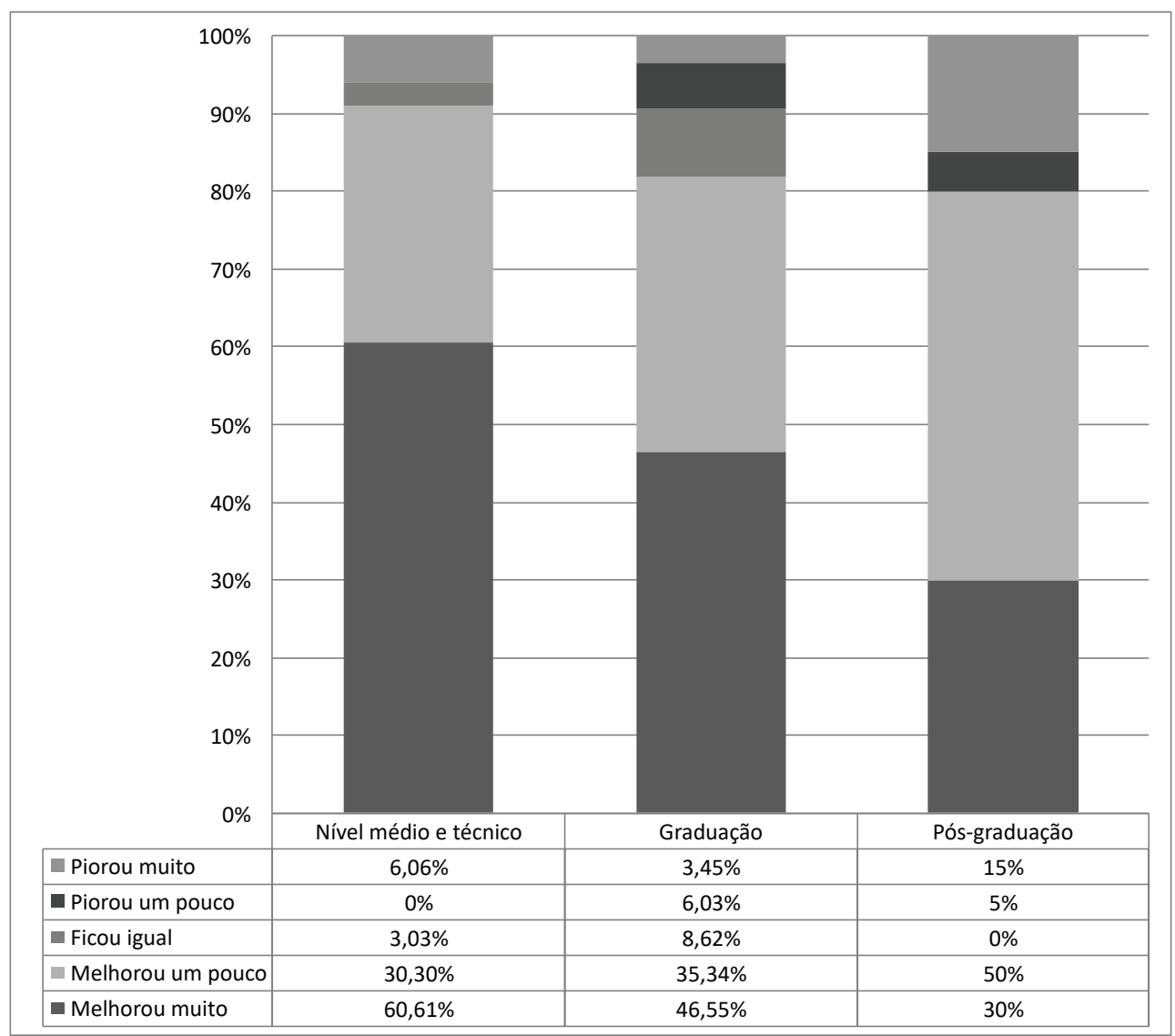

Fonte: Elaboração própria.

A percepção da melhoria de imagem motivada pela participação no projeto apresenta-se de forma ampla entre egressos de todas as edições, como se pode perceber no Gráfico 2. Os maiores percentuais são percebidos nos egressos das edições mais recentes, o que diminui levemente nos participantes de edições anteriores, com exceção dos anos de 2006 e 2009, que apresentaram percentuais próximos das edições mais recentes. 
Gráfico 2 - Impactos do PJB na imagem pública do Poder Legislativo por edição

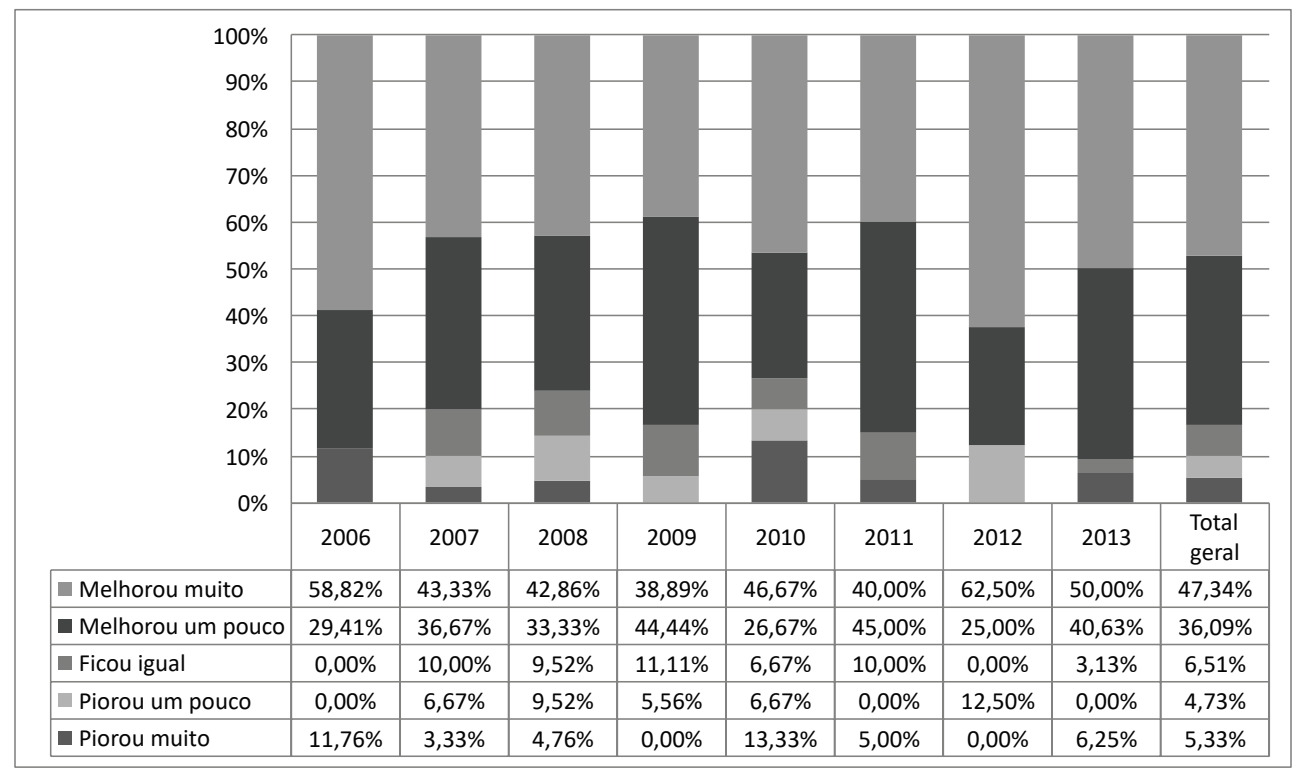

Fonte: Elaboração própria.

Pergunta-se qual o nível de conhecimento deles sobre o Poder Legislativo antes e depois do PJB. Conforme consta na Quadro 6, há uma significativa elevação em todos os itens.

Quadro 6 - Nível de conhecimento acerca do Poder Legislativo antes e após a participação no PJB

\begin{tabular}{|l|l|l|l|l|l|}
\hline Antes do PJB & $\mathbf{N}$ & $\mathbf{\%}$ & Depois do PJB & $\mathbf{N}$ & $\%$ \\
\hline Nenhum conhecimento & 16 & 9,46 & Nenhum conhecimento & 1 & 0,59 \\
\hline Pouco conhecimento & 94 & 55,62 & Pouco conhecimento & 12 & 7,10 \\
\hline $\begin{array}{l}\text { Nível médio de } \\
\text { conhecimento }\end{array}$ & 56 & 33,13 & $\begin{array}{l}\text { Nível médio de } \\
\text { conhecimento }\end{array}$ & 65 & 38,46 \\
\hline $\begin{array}{l}\text { Nível elevado de } \\
\text { conhecimento }\end{array}$ & 3 & 1,77 & $\begin{array}{l}\text { Nível elevado de } \\
\text { conhecimento }\end{array}$ & 91 & 53,84 \\
\hline Total & 169 & 100 & Total & 169 & 100 \\
\hline
\end{tabular}

Fonte: Elaboração própria.

A melhoria da imagem está relacionada com os conhecimentos adquiridos na experiência de simulação parlamentar, o que se verifica no cruzamento das respostas acerca do conhecimento das funções e atribuições do Legislativo após 
o PJB e a imagem desse Poder segundo os egressos (Quadro 7). Somando-se os percentuais de respostas nos dois maiores níveis de imagem (melhorou um pouco e melhorou muito) e aquelas que também apontaram os dois maiores níveis de conhecimento do Legislativo (nível médio e nível elevado), chega-se a 78,7\%, o que indica uma possível correlação entre maior conhecimento das atribuições do Poder Legislativo e o desenvolvimento de uma melhor imagem dessa instituição.

Quadro 7 - Cruzamento do nível de conhecimento após o PJB e a imagem pública do Poder Legislativo

\begin{tabular}{|c|c|c|c|c|c|c|c|c|c|c|}
\hline Imagem & \multirow{2}{*}{$\begin{array}{l}\text { Piorou } \\
\text { muito }\end{array}$} & \multirow[b]{2}{*}{$\%$} & \multirow{2}{*}{$\begin{array}{l}\text { Piorou } \\
\text { um } \\
\text { pouco }\end{array}$} & \multirow[b]{2}{*}{$\%$} & \multirow{2}{*}{$\begin{array}{l}\text { Ficou } \\
\text { igual }\end{array}$} & \multirow[b]{2}{*}{$\%$} & \multirow{2}{*}{$\begin{array}{l}\text { Melhorou } \\
\text { um } \\
\text { pouco }\end{array}$} & \multirow[b]{2}{*}{$\%$} & \multirow{2}{*}{$\begin{array}{l}\text { Melhorou } \\
\text { muito }\end{array}$} & \multirow[b]{2}{*}{$\%$} \\
\hline $\begin{array}{l}\text { Conhecimento } \\
\text { do Legislativo }\end{array}$ & & & & & & & & & & \\
\hline $\begin{array}{l}\text { Nenhum } \\
\text { conhecimento }\end{array}$ & 1 & 0,59 & 0 & 0,00 & 0 & 0,00 & 0 & 0,00 & 0 & 0,00 \\
\hline $\begin{array}{l}\text { Pouco } \\
\text { conhecimento }\end{array}$ & 1 & 0,59 & 3 & 1,78 & 1 & 0,59 & 5 & 2,96 & 2 & 1,18 \\
\hline $\begin{array}{l}\text { Nível médio de } \\
\text { conhecimento }\end{array}$ & 5 & 2,96 & 3 & 1,78 & 6 & 3,55 & 29 & 17,16 & 22 & 13,02 \\
\hline $\begin{array}{l}\text { Nível } \\
\text { elevado de } \\
\text { conhecimento }\end{array}$ & 2 & 1,18 & 2 & 1,18 & 4 & 2,37 & 27 & 15,98 & 56 & 33,14 \\
\hline
\end{tabular}

Fonte: Elaboração própria.

O nível de conhecimento também foi associado a tópicos específicos, como a compreensão da relação entre Legislativo e Executivo, entendimento das funções do Poder Legislativo, das comissões permanentes/Plenário, o papel dos parlamentares na dinâmica legislativa, o papel das lideranças partidárias, a relação da base parlamentar de apoio ao governo versus oposição, o papel das lideranças partidárias, e o papel dos partidos políticos no Congresso Nacional. Em todos esses itens, o nível mais elevado de aprendizado, ou seja, respostas que indicaram bastante contribuição do projeto ficaram entre $47,33 \%$ e $84,61 \%$, como mostra a Quadro 8. 


\section{Quadro 8 - Nível de conhecimento acerca do Poder Legislativo após a participação no PJB}

\begin{tabular}{|c|c|c|c|}
\hline Tópicos & Resposta & $\mathbf{N}$ & $\%$ \\
\hline \multirow{3}{*}{$\begin{array}{l}\text { Compreensão da relação entre Legislativo e } \\
\text { Executivo }\end{array}$} & em nada & 2 & 1,18 \\
\hline & um pouco & 37 & 21,89 \\
\hline & bastante & 130 & 76,92 \\
\hline \multirow{3}{*}{ Entendimento das funções do Poder Legislativo } & em nada & 1 & 0,59 \\
\hline & um pouco & 29 & 17,16 \\
\hline & bastante & 139 & 82,24 \\
\hline \multirow{3}{*}{$\begin{array}{l}\text { Entendimento das funções das comissões e do } \\
\text { Plenário }\end{array}$} & em nada & 2 & 1,18 \\
\hline & um pouco & 24 & 14,20 \\
\hline & bastante & 143 & 84,61 \\
\hline \multirow{3}{*}{$\begin{array}{l}\text { Compreensão do papel dos parlamentares na } \\
\text { dinâmica legislativa }\end{array}$} & em nada & 3 & 1,77 \\
\hline & um pouco & 35 & 20,71 \\
\hline & bastante & 131 & 77,51 \\
\hline \multirow{3}{*}{$\begin{array}{l}\text { Entendimento da relação entre base versus } \\
\text { oposição }\end{array}$} & em nada & 19 & 11,24 \\
\hline & um pouco & 70 & 41,42 \\
\hline & bastante & 80 & 47,33 \\
\hline \multirow{3}{*}{ Entendimento do papel das lideranças partidárias } & em nada & 18 & 10,65 \\
\hline & um pouco & 70 & 41,42 \\
\hline & bastante & 81 & 47,92 \\
\hline \multirow{3}{*}{$\begin{array}{l}\text { Compreensão do papel dos partidos políticos no } \\
\text { Congresso Nacional }\end{array}$} & em nada & 20 & 11,83 \\
\hline & um pouco & 58 & 34,32 \\
\hline & bastante & 91 & 53,84 \\
\hline
\end{tabular}

Fonte: Elaboração própria.

\section{Confiança política}

A variação da confiança em relação ao Poder Legislativo também foi sensível (Quadro 9). Foi perguntado qual seria o nível de confiança antes e, em outra questão, qual passou a ser o nível de confiança após o PJB, com ambas as questões respondidas no mesmo questionário. Fica evidente nos resultados uma variação significativa da confiança. Enquanto a maioria dos egressos considera seu nível de confiança no Legislativo, antes do PJB, nos dois menores níveis (51,89\%), após a simulação parlamentar, $85,2 \%$ se identificam com os dois maiores níveis. Esse resultado aponta para a inversão de uma lógica comum também no eleitorado em geral, no qual se verifica um baixo nível de confiança no Parlamento, sendo que, numa escala de 0 a 100, o Instituto Brasileiro de Opinião e Estatística (Ibope) (2014) encontrou 35 pontos para a confiança no Congresso Nacional, o que, comparado a outras instituições sociais, é menor apenas que os partidos políticos, entre diversas instituições sociais. 
Quadro 9 - Confiança no Poder Legislativo antes e após o PJB

\begin{tabular}{|l|l|l|l|l|l|}
\hline Confiança antes & $\mathbf{N}$ & $\mathbf{\%}$ & Confiança após & $\mathbf{N}$ & $\mathbf{\%}$ \\
\hline Nenhuma & 16 & 9,47 & Nenhuma & 6 & 3,55 \\
\hline Quase nenhuma & 70 & 41,42 & Quase nenhuma & 19 & 11,24 \\
\hline Alguma & 78 & 46,15 & Alguma & 90 & 53,25 \\
\hline Muita & 5 & 2,96 & Muita & 54 & 31,95 \\
\hline
\end{tabular}

Fonte: Elaboração própria.

Um dado relevante desse levantamento é o fato de que apenas 4,14\% dos egressos tiveram uma variação negativa e outros $37,28 \%$ afirmaram que não houve variação da confiança; contudo, 42,60\% variara-m um nível e outros 15,98\% indicaram dois ou três níveis de variação positiva da confiança no Poder Legislativo. Para efeito de comparação, transpondo-se a escala utilizada de quatro níveis de confiança deste estudo para uma escala centesimal ${ }^{9}$, verifica-se aproximadamente 47 pontos como percepção para o período anterior e 71 pontos após a participação, o que pode indicar um perfil diferenciado do público atendido em relação ao eleitorado nacional e também um aperfeiçoamento considerável do nível de confiança dos jovens no Poder Legislativo.

O fator gênero não apresentou diferença significativa quando correlacionado com o nível de confiança no Poder Legislativo. Os percentuais são similares para homens e mulheres após o PJB, com leves variações ${ }^{10}$. Isso mostra que o impacto positivo na confiança política dos jovens ocorre de maneira homogênea, sem diferenciação expressiva em relação à variável gênero. Isso significa que o efeito é similar em homens e mulheres.

De forma semelhante ao fator gênero, o nível educacional não indicou forte relação com o nível de confiança pós-PJB; porém, há variações. Quando somados os dois maiores níveis de confiança em relação ao nível de formação, foram encontrados: $81,81 \%$ - nível médio e técnico; $85,34 \%$ - graduação; e $90 \%$ - pósgraduação. Em comparação com a imagem institucional, há uma situação inversa, já que o nível de confiança cresce levemente acompanhando a maior formação, enquanto que a melhoria da imagem apresentou leve decréscimo. Esses dados são convergentes com as demais pesquisas sobre os projetos de parlamento jovem

\footnotetext{
${ }^{9}$ Transposição realizada da seguinte forma: nenhuma confiança $=0$, quase nenhuma $=33,33$, alguma $=66,66 \mathrm{e}$ muita $=100$.

${ }^{10}$ Ao serem segmentados por gênero, os dados da Quadro 9 (que mostram o total das respostas) na coluna confiança após o PJB são similares, como por exemplo no caso de alguma confiança (26\% para homens e $27,25 \%$ para mulheres) e de muita confiança ( $16 \%$ para homens e $15,95 \%$ para mulheres).
} 
estaduais, a exemplo do estudo de Gonçalves e Casalecchi (2013) e de Fuks (2014), ambos sobre o Parlamento Jovem Mineiro. Talvez a escolaridade não seja razão de grandes variações nas respostas porque se trata de um público relativamente homogêneo, com faixa etária similar e consequente grau de instrução. Afinal, o público preferencial dos projetos de simulação parlamentar como o PJB são os estudantes do ensino médio. Após o PJB, ao responderem ao questionário, é que parte dos jovens já alcançou o ensino superior.

Como forma de avaliar se os egressos com maior tempo decorrido da participação no projeto teriam uma menor confiança no Legislativo, foram agrupados os dois menores níveis e também os dois maiores, conforme pode ser visualizado no Gráfico 3.

\section{Gráfico 3 - Impactos do PJB na imagem pública do Poder Legislativo por edição}

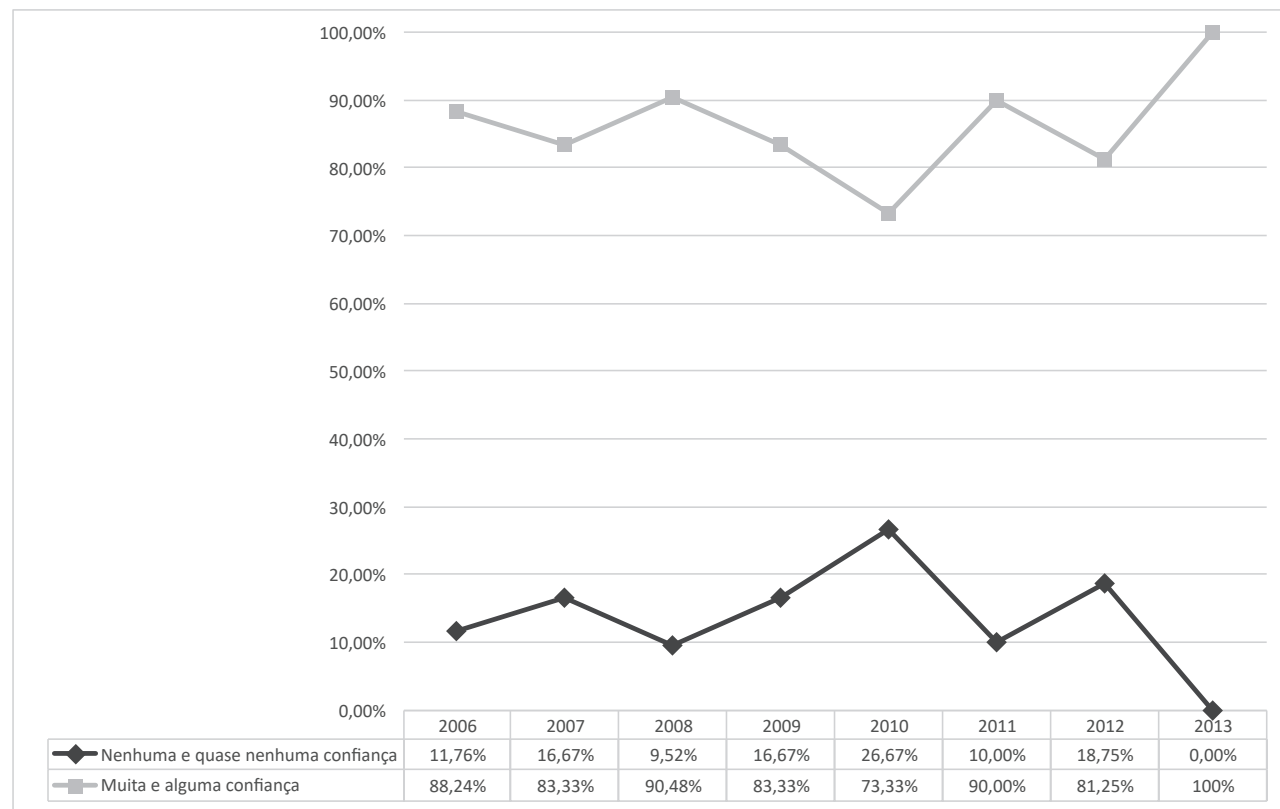

Fonte: Elaboração própria.

Por meio dessa análise, é possível perceber certa manutenção dos níveis de confiança no Poder Legislativo com o passar dos anos decorridos da participação no projeto, apesar de uma leve diminuição dessa confiança dos egressos nos quatro anos posteriores à participação. Um quantitativo a ser destacado é que $29,58 \%$ (50 respostas) dos egressos em geral afirmaram ter muita confiança no Poder Legislativo após o PJB, o que demonstra um efeito significativo, já que apenas cinco afirmaram ter muita confiança no Parlamento em relação ao período anterior ao projeto $(2,98 \%)$. 
O levantamento indica uma possível correlação positiva entre a melhoria da imagem e da confiança no Poder Legislativo. Como verificado na Quadro 10, 79,29\% dos jovens afirmaram ter ocorrido uma melhoria considerável da imagem e também informaram ter alguma ou muita confiança no Poder Legislativo. Respostas no maior nível de confiança no Poder Legislativo e no maior nível de impacto do PJB na sua imagem somaram $20,71 \%$.

Dados qualitativos do questionário reforçam essa correlação positiva entre a participação no PJB e a melhora da imagem desse Poder perante os participantes, assim como ampliação da confiança institucional, como se vê em alguns dos depoimentos escritos pelos próprios jovens:

O aprendizado me fez confiar mais no Legislativo. Ao compreender, consigo defender o Legislativo naquilo que conheço e que os outros ainda têm ideia distorcida (Resposta 56, 23 anos, masculino, interior/SC).

O PJB me influenciou muito, me fez acreditar ainda mais no Legislativo federal, fortaleceu em mim a confiança na democracia do País, pois eu vivi na prática a atividade legislativa (Resposta 171, 20 anos, masculino, capital/MS).

Hoje, tenho uma visão mais positiva da atuação parlamentar, pois consigo compreender como as coisas funcionam na política. Vi na prática que o Congresso Nacional está de portas abertas, para receber, informar e ouvir cada cidadão. Isso faz a gente confiar (Resposta 124, 19 anos, feminino, interior/GO).

Meu interesse sobre o Legislativo aumentou e passei a acompanhar a agenda e atividade da casa e dos parlamentares do meu estado e os mais relevantes a nível nacional (Resposta 3, 24 anos, masculino, capital/GO).

\section{Quadro 10 - Cruzamento da confiança, após o PJB, e da imagem do Poder Legislativo}

\begin{tabular}{|l|l|l|l|l|l|l|l|l|}
\hline $\begin{array}{l}\text { Confiança no Poder } \\
\text { Legislativo }\end{array}$ & $\begin{array}{l}\text { Nenhuma } \\
\text { confiança }\end{array}$ & $\begin{array}{c}\text { Quase } \\
\text { nenhuma } \\
\text { confiança }\end{array}$ & $\%$ & $\begin{array}{c}\text { Alguma } \\
\text { confiança }\end{array}$ & $\%$ & $\begin{array}{c}\text { Muita } \\
\text { confiança }\end{array}$ & $\%$ \\
\hline Piorou muito & 2 & 1,18 & 4 & 2,37 & 3 & 1,78 & 0 & 0,00 \\
\hline Piorou um pouco & 1 & 0,59 & 3 & 1,78 & 3 & 1,78 & 1 & 0,59 \\
\hline Ficou igual & 0 & 0,00 & 4 & 2,37 & 6 & 3,55 & 1 & 0,59 \\
\hline Melhorou um pouco & 0 & 0,00 & 5 & 2,96 & 44 & 26,04 & 12 & 7,10 \\
\hline Melhorou muito & 0 & 0,00 & 2 & 1,18 & 43 & 25,44 & 35 & 20,71 \\
\hline
\end{tabular}

Fonte: Elaboração própria. 
Os dados sugerem que a confiança política dos jovens é fortalecida com o desenvolvimento de conhecimentos sobre as funções do Poder Legislativo. A experiência direta proporcionada pelo projeto de simulação parlamentar contribui para que os jovens participantes adquiram conhecimento sobre o processo legislativo. Desse modo, como salienta Giddens (1990), os aspectos cognitivos se somam aos elementos de crença no sistema político, dois fatores essenciais para a construção da confiança política. Essa compreensão favorece que os jovens entendam os procedimentos que regem as práticas dos parlamentares, contextualizando seus desafios e limitações. Assim, tornando-se mais permeável à participação dos jovens, o Poder Legislativo pode ser fortalecido, bem como sua imagem pública perante a juventude. Afinal, como argumenta McCoy (2000), a confiança institucional pode se tornar um antídoto às recorrentes crises das democracias, contribuindo para a legitimidade do regime e a estabilidade política.

\section{Conclusões}

O presente estudo indica que a participação no projeto Parlamento Jovem Brasileiro tem gerado uma melhoria significativa dos níveis de conhecimento acerca de temáticas relevantes sobre as funções e o funcionamento do Poder Legislativo. Os dados acerca do impacto na imagem pública levam à conclusão de que a experiência altera significativamente o conceito do Legislativo, alterase consideravelmente a sua reputação perante os jovens egressos. Ao participar diretamente da discussão de temáticas relevantes para a sociedade e da disputa de posições e ideias na simulação parlamentar, a política passa a fazer parte da vida do indivíduo, facilitando a formação de uma opinião esclarecida.

Existem vários aspectos da pesquisa que demonstram que, após a experiência do PJB, os jovens entrevistados passaram a encarar a política como parte de seu cotidiano. Um montante de $66 \%$ de estudantes afirmaram que, após o PJB, adquiriram o hábito de conversar sobre política no ambiente familiar, incluindo amigos e vizinhos. Mais de $48 \%$ dos jovens passaram a publicar e compartilhar opinião sobre política em redes sociais e blogs. Cerca de $26 \%$ dos jovens informaram que passaram a participar de atividades promovidas por organizações nãogovernamentais, instituições filantrópicas, comunitárias e voluntariado após o PJB. Além disso, $24 \%$ dos respondentes passaram a participar da política estudantil de suas escolas e universidades.

A melhoria da imagem do Legislativo como resultado da participação não se apresenta como uma visão efêmera, como se poderia supor já que o PJB representa um estímulo ao aprendizado com período limitado de apenas uma semana 
contraposto a diversos outros estímulos no âmbito escola/universidade, de relações pessoais próximas (família, amigos e colegas de trabalho) e da mídia que tem sua linguagem e enfoque próprios para abordar a política, o que nem sempre facilita a compreensão acerca do funcionamento do Congresso Nacional. Essa relativa permanência da imagem fica evidente ao constatarmos que os dois maiores níveis ${ }^{11}$ de melhoria somados representam de $73 \%$ a $90 \%$ e não há a constatação de uma tendência unidirecional de queda dessa percepção com o maior tempo decorrido da interação.

A criação de escolas do Legislativo, de veículos de comunicação e de programas de relacionamento e aproximação com os cidadãos, além das formas de participação popular diretamente no processo legislativo, se apresentam como estratégias das instituições parlamentares de se contrapor ao descrédito e desconfiança verificados largamente nas democracias modernas. O Parlamento Jovem Brasileiro, como uma dessas iniciativas, demonstra, por meio dos resultados parciais deste levantamento, que é possível inverter essa lógica por meio de ações educativas sistemáticas e continuadas. Quando comparados os níveis de confiança no Parlamento da população brasileira verificados pelo lbope e os níveis verificados junto aos egressos, há uma diferença positiva expressiva. Após a participação na simulação parlamentar, os jovens passam de um nível de desconfiança (47 em 100 pontos) para um nível de relativa confiança (71 pontos), com baixíssima diferença entre homens e mulheres. Esse resultado relativo à confiança no Legislativo apresenta uma leve tendência de melhoria conforme aumenta o nível educacional dos egressos, o que acontece de forma invertida em relação à imagem. Também é possível identificar, em termos descritivos, uma correlação positiva entre a melhoria da imagem pública e a confiança em relação ao Poder Legislativo, apesar de que diversas variáveis podem atuar para a construção dessa relação entre o cidadão e as instituições representativas.

Este artigo apresenta uma parte dos resultados de um amplo levantamento junto aos egressos de dez edições do projeto Parlamento Jovem Brasileiro da Câmara dos Deputados, sendo que novas análises desses dados utilizando-se de métodos inferenciais poderão trazer conhecimentos mais amplos acerca dos efeitos da participação no engajamento cívico (participação política convencional e não convencional) e da confiança em relação a outras instituições, além do Legislativo. Estudos semelhantes com egressos de projetos correlatos e a posterior comparação com esse levantamento podem trazer relevantes conhecimentos para os impactos desse tipo de projeto para a cidadania do público jovem.

\footnotetext{
${ }^{11}$ Escala de cinco níveis relativa ao efeito do PJB na imagem do Parlamento com as alternativas: melhorou muito, melhorou um pouco, ficou igual, piorou um pouco e piorou muito.
} 
Mais do que um alto nível de melhoria da imagem pública do Poder Legislativo e de ampliação da confiança institucional, este estudo indica que esses efeitos podem ser duradouros, o que reforça a importância desse tipo de estratégia para o fortalecimento dessa instituição, que é um dos pilares da democracia.

\section{Referência bibliográfica}

AldÉ, A; Mendes, G; Figueiredo, M. Imprensa e eleições presidenciais. In: LIMA, Venício A. de (Org.) A mídia nas eleições de 2006. São Paulo: Editora Fundação Perseu Abramo, 2007.

ARENDT, H. A condição humana. Rio de Janeiro: Tempo Brasileiro, 1983.

Augras, M. Opinião pública: teoria e pesquisa. 3. ed. Petrópolis: Vozes, 1978.

BALDISSERA, Rudimar. Significação e comunicação na construção da imagemconceito. Revista Fronteiras - Estudos Midiáticos, São Leopoldo (RS), Unisinos, v. 10, n. 3, p. 193-200, set./dez. 2008.

BAPTISTA, Érica Anita et al. Jovens eleitores e novas tecnologias: percepções da política e participação. Revista do Legislativo. Belo Horizonte, v.5, n.1, jan., 2013, p.124-132.

BAUMAN, Z. Vidas para consumo: a transformação das pessoas em mercadorias. Rio de Janeiro: Jorge Zahar Ed., 2008a.

BAUMAN, Zygmunt. A sociedade individualizada: vidas contadas e histórias vividas. Rio de Janeiro: Zahar, 2008b.

BAUMAN, Z. Legisladores e intérpretes: sobre modernidade, pós-modernidade e intelectuais. Rio de Janeiro: Zahar, 2010.

BAUMAN, Zygmunt. Para que serve a sociologia? Rio de Janeiro: Zahar, 2015.

BOLTANSKI, Luc. El amor y la justicia como competencias. Buenos Aires: Amorrotu, 2000.

BosCHI, R. Instituições políticas, reformas estruturais e cidadania: dilemas da democracia no Brasil. In: SEMINÁRIO INTERNACIONAL SOBRE DEMOCRACIA NA AMÉRICA LATINA, 2004, Santiago. Anais... Chile, 2004.

BOURDIEU, Pierre. A opinião pública não existe. In: . Questões de sociologia. Lisboa: Fim de Século, 2003. p. 233-246.

CASTELLS, Manuel. A Galáxia Internet: reflexões sobre a internet, negócios e a sociedade. Rio de Janeiro: Zahar, 2003.

CASTRO, M. M.M. Sujeito e estrutura no comportamento eleitoral. Revista Brasileira de Ciências Sociais, Rio de Janeiro, v. 20, p. 7-19, 1992.

CERVI, E. U. Opinião pública e política no Brasil: o que o brasileiro pensa sobre política e por que isso interessa à democracia. Rio de Janeiro: luperj, 2006. 359 f. Tese (Doutorado em Ciência Política) - Instituto Universitário de Pesquisas do Rio de Janeiro, Rio de Janeiro.

Champagne, P. Formar a opinião. São Paulo: Vozes, 1998. 
Colen, M. C. L. As covariantes da confiança política na América Latina. Opinião Pública, Campinas, v. 16, n. 1, p. 1-27, 2010.

DAHL, R. Um prefácio à teoria democrática. Rio de Janeiro: J. Zahar, 1989.

DALTON, R. J. Democratic challenges, democratic choices: the erosion of political support in advanced industrial democracies. USA: Oxford University Press, 2007.

Downs, A. An economic theory of democracy. New York: Harper \& Row, 1957.

ESTEVES, J. P. Legitimação pelo procedimento e deslegitimação da opinião pública. In: SANTOS, José Manuel. O pensamento de Niklas Luhmann. Covilhã: Universidade da Beira Interior, 2005. p. 281-320.

FERES Jr., J.; EISENBERG, J. Dormindo com o inimigo: uma crítica ao conceito de confiança. Dados - Revista de Ciências Sociais, Rio de Janeiro, v. 49, n. 3, p. 457-482, 2006.

FigueIREDo, M. A decisão do voto-democracia e nacionalidade. São Paulo: editora Sumaré, 1991.

FigueIREDo, A.; LIMONGI, F. O próximo passo. Revista Plenarium, Brasília, Coordenação de Publicações da Câmara dos Deputados, ano IV, n. 4, p.36-52, maio 2007.

FIORINA, M. Retrospective voting in american national elections. New Haven: Yale University Press, 1981.

FuKs, Mario. Explicando os efeitos de programas de socialização política: a experiência do Parlamento Jovem no Brasil. Opinião Publica, Campinas, v. 20, n. 3, p.425-449, 2014.

GIDDEnS, A. As consequências da modernidade. São Paulo: Unesp, 1990. A constituição da sociedade. São Paulo: Martins Fontes, 2009.

GOMES, Wilson. Transformação da política na era da comunicação de massa. São Paulo: Paulus, 2004.

GOMES, Marcelo Bolshaw. Hermenêutica, teoria política e imagem pública. In: CONGRESSO dA ASSOCIAÇÃo BRASILEIRA DE PESQUISADORES EM COMUNICAÇÃo E PolítICA (COMPolítICA), 1., novembro 2006, Salvador - BA. Anais... Salvador: Compolítica, 2006. Disponível em: http://www.compolitica.org/home/?page_id=70. Acesso em: 4/3/2015.

GonçALVES, Guilherme Quaresma; CASALECCHI, Gabriel Ávila. O impacto do Parlamento Jovem sobre a confiança dos jovens mineiros. Cadernos da Escola do Legislativo, Belo Horizonte, v. 15, n. 24, p. 71-103, 2013.

Habermas, J. Opinião pública e poder. In: CoHn, Gabriel. Comunicação e indústria cultural. São Paulo: Companhia Editora Nacional, 1971.

. Mudança estrutural na esfera pública. São Paulo: Tempo Brasileiro, 1984. . Historia y crítica de la opinión pública. Barcelona: G. Gili, 1994. . Comentários à Ética do Discurso. Lisboa: Instituto Piaget, 1999. 202 p. . O discurso filosófico da modernidade. São Paulo: Martins Fontes, 2002. 540 p. INSTITUTO BRASILEIRO DE OPINIÃo E ESTATístICA (IBOPE). Após queda acentuada em 2013, Índice de Confiança Social se estabiliza. Divulgação da pesquisa realizada em 
10 de setembro de 2014 sem indicação de autoria. Ibope, 2014. Disponível em: <http://www.ibope.com.br/pt-br/noticias/Paginas/Ap\%C3\%B3s-queda-acentuadaem-2013,Indice-de-Confianca-Social-se-estabiliza.aspx.> Acesso em: 10/2/2015.

JOSHI, D.; ROSENFIELD, E. MP. Transparency, communication links and social media: a comparative assessment of 184 parliamentary websites. The Journal of Legislative Studies, v. 19, n. 4, p. 526-545, 2013. DOI: 10.1080/13572334.2013.811940.

Johnson, Allan G. Dicionário de sociologia. Rio de Janeiro: Jorge Zahar Editor, 1997.

KEY, V. O. The responsible electorate: rationality in presidencial voting. 1936-1966. Cambridge: Harvard University Press, 2013.

LESTON-BANDEIRA. Studying the relationship between Parliament and citizens. The Journal of Legislative Studies, v. 18, n. 3-4, p. 265-274, Sep.-Dec. 2012.

LIJPHART, A. Democracy in the 21st century: can we be optimistic? European Review, v. 9, n. 2, p. 169-184, 2001.

LIPPMAnN, W. Opinião Pública. Petrópolis: Vozes, 2008.

LOPES, D. M. N. N. Para pensar a confiança e a cultura política na América Latina. Opinião Pública, Campinas, v. 10, n. 1, 2004, p. 162-187.

Luhmann, N. A realidade dos meios de comunicação. São Paulo: Paulus, 2005.

Matteuccl, Nicola. Opinião pública. In: Bоввıо, Norberto et al. Política. Dicionário de política. Brasília: Editora da UnB, 1986. p. 842-845.

MccoY, J. Political learning and democratization in Latin America: do politicians learn from crisis? Miami: University of Miami Press, 2000.

MIGUEL, Luis F. Representação política em 3-D. Elementos para uma teoria ampliada da representação política. Revista Brasileira de Ciências Sociais, v. 18, n. 51, p. 123140, fev. 2003.

- Impasses da accountability: dilemas e alternativas da representação política. Revista de Sociologia Política, Curitiba, s.v, n. 25, p. 25-38, nov. 2005.

A mídia e o declínio da confiança na política. Sociologias, Porto Alegre, v. 10, n. 19, p. 250-273, jan./jun. 2008.

MoIsÉs, J.A. Democracia e desconfiança de instituições democráticas. Edição do autor, 2009.

Nöelle-Neuman, E. Pesquisa eleitoral e clima de opinião. Opinião Pública, v. 1, n. 2, 1993.

Noleto Filho, Pedro Aquino. Mídia e política na imagem do Congresso. Brasília: Edições Câmara, 2014. Versão eletrônica disponível em: <http://bd.camara.gov.br/ bd/bitstream/handle/bdcamara/18759/midia_politica_noleto.pdf?sequence=1> Acessado em: 04/03/15.

Norris, P. Critical citizens: global support for democratic government. USA: Oxford University Press, 1999.

- Democratic deficit - Critical citizens revisited. Cambridge: Cambridge University Press, 2011.OfFE, C. How can we trust our fellow citizens? In: WARREN, M. E. (Ed.). Democracy and trust. Cambridge: Cambridge University Press, 1999. 
OrTIZ, Anderson de Almeida Cano. Opinião pública, enxames e contornos visíveis da esfera. In: EnCONTRO DA COMPolítICA, 4., 2011, Rio de Janeiro. Anais... Rio de Janeiro: Universidade do Estado do Rio de Janeiro, 13 a 15 de abril de 2011. Disponível em: <http://www.compolitica.org/home/wp-content/uploads/2011/03/AndersonOrtiz.pdf.> Acesso em: 22/07/16.

PEREIRA, Alexandre Barbosa. Muitas palavras: a discussão recente sobre juventude nas ciências sociais. Ponto Urbe, n. 1, 2007. Disponível em: <http://pontourbe. revues.org/1203>. Acesso em: 21/03/15.

PINTO, Céli Regina Jardim. Teorias da democracia: diferenças e identidades na contemporaneidade. Porto Alegre: EdIPUCRS, 2004.

PORTO, M. A crise de confiança política e suas instituições: os mídia e a legitimidade da democracia. In: BAQUero, Marcello (Org.). Condicionantes da consolidação democrática: ética, mídia e cultura política. Porto Alegre: Ed. da UFRGS, 1996.

PoWer, T. J.; JAMINSON, G. D. Desconfiança política na América Latina. Opinião Pública, Campinas , v. 11, n. 1, p.64-93, mar. 2005.

Ribeiro, Ednaldo E. A. Confiança política na América Latina: evolução recente e determinantes individuais. Revista de Sociologia e Política, Curitiba , v. 19, n. 39, p. 167-182, 2011.

SÁ, Fernando A. Opinião pública, imprensa e parlamento. Achegas.net, Rio de Janeiro, v. 2, n. 15, 2004. Disponível em: <http://www.achegas.net/numero/quinze/ fernando_sa_15.htm.> Acesso em: 7/7/2014.

StokeR, G. Why politics matters: making democracy work. Basingstoke: Palgrave Macmillan, 2006.

TELLES, Helcimara de S.; DIAS, Mariana. Condutas políticas, valores e voto dos eleitores jovens de Belo Horizonte. Revista do Legislativo. Belo Horizonte, n. 43, p.82-102, jan. 2010.

Thiollent, Michel. Metodologia da pesquisa-ação. São Paulo: Cortez, 1986.

Thompson, J. B. Ideologia e cultura moderna. Petrópolis: Vozes, 1995.

TILly, C. Democracy. New York: Cambridge University Press, 2008.

Tribunal SUPERIOR Eleitoral. Estatísticas do eleitorado por sexo e faixa etária. 2014. Disponível em: <http://www.tse.jus.br/eleitor/estatisticas-de-eleitorado/ estatistica-do-eleitorado-por-sexo-e-faixa-etaria>. Acessado em: 23/12/2015.

. Estatísticas do eleitorado. 2014. Disponível em: <http://www.tse.jus.br/ eleicoes/estatisticas/estatisticas-candidaturas-2014/estatisticas-eleitorais-2014eleitorado>. Acessado em: 23/12/2015.

VIÁ, Sara. Opinião pública: técnicas de formação e problemas de controle. São Paulo: Loyola, 1983.

Weber, Maria Helena. A imagem pública. In: RubIM , Albino (Org.) Comunicação e política: conceitos e abordagens. Salvador: EdUFBA, 2004. p. 262-278.

O estatuto da imagem pública na disputa política. Eco-Pós, Rio de Janeiro,

v. 12, n. 3, p. 11-26, set./dez. 2009. 


\section{Antonio Teixeira de Barros}

Possui doutorado em Sociologia pela Universidade de Brasília e pós-doutorado em Comunicação pela Universidade Fernando Pessoa, Portugal. Docente e pesquisador do Programa de Mestrado em Ciência Política do Centro de Formação, Treinamento e Aperfeiçoamento da Câmara dos Deputados (Cefor). Contato: antonibarros@gmail.com

\section{Lúcio Meireles Martins}

Possui especialização em Comunicação Empresarial pela UDC-Foz do Iguaçu e em Instituições e Processos Políticos do Legislativo no Centro de Formação, Treinamento e Aperfeiçoamento da Câmara dos Deputados (Cefor). É mestre em Poder Legislativo pelo Cefor/Câmara dos Deputados. Atualmente chefia o Serviço de Relacionamento Institucional da Consultoria Legislativa da Câmara dos Deputados. Contato: luciogoiano@hotmail.com 
